\title{
Acute smell and taste loss in outpatients: all infected with SARS-CoV-2?*
}

\author{
M. Renaud', A. Leon', G. Trau', L. Fath', S. Ciftci', Y. Bensimon', \\ A. Venkatasamy ${ }^{3}$, C. Debry ${ }^{1,2}$
}

'Department of Otolaryngology, Head and Neck Surgery, University Hospital of Strasbourg, France

INSERM Unit 1121, Strasbourg, France

${ }^{3}$ Department of Radiology 1, University Hospital of Strasbourg, France
Rhinology 58: 4, 406 - 409, 2020

https://doi.org/10.4193/Rhin20.199

*Received for publication:

April 28, 2020

Accepted: May 26, 2020

\section{To the Editor:}

During SARS-CoV-2 pandemic, our region (Alsace, East of France) became a Covid-19 cluster quite early in Europe. Loss of smell and taste was quickly flagged by the Ears-Nose and Throat scientific community as a potential warning signs of SARS-CoV-2 infection (1). Many patients and medical/paramedical workers with mild to moderate form of SARS-CoV-2 infection complained about their loss of sense of smell and taste to our ENT department. The aim of our study was to compare the characteristics of loss of smell and taste between patients with a clinical diagnosis of SARS-CoV-2 infection to patients with a RT-PCR diagnosis.

This retrospective single-study included ambulatory adult pa- tients with loss of smell and taste who had either a RT-PCR-proven SARS-CoV-2 diagnosis ("PCR +" group) or a clinical diagnosis of SARS-CoV-2 ("PCR -" group). Patients were referred to our center by their general practitioner and a 28-questions survey (Annex 1) was sent to them by e-mail. Duration of symptom was defined by the time between the onset of loss of smell and taste and the day of the participation to this study. Self-rating of the severity of symptoms was assessed by a 5-points scale ${ }^{(2)}$ ranging from 1, normal to 5, total loss (Annex 1). Patients were excluded for: history of olfactory loss $(n=8)$, incomplete questionnaire $(n=14)$ and hospitalization for the SARS-CoV-2 $(n=2)$. Informed consent was obtained from all patients and the study was approved by the Ethics Committee of the University Hospital of Strasbourg on April 3, 2020 (CE-2020-31).

Table 1. Characteristics of the study population.

\begin{tabular}{|c|c|c|c|c|}
\hline Characteristics & $\begin{array}{l}\text { SARS-CoV-2 pa-tients } \\
(n=347)\end{array}$ & $\begin{array}{l}\text { "PCR+"patients } \\
\qquad(n=97)\end{array}$ & $\begin{array}{l}\text { "PCR-" patients } \\
(n=250)\end{array}$ & p-value "PCR+" vs. "PCR-" \\
\hline Median age [range] & $37[18-78]$ & $35[20-73]$ & $38[18-78]$ & 0.053 \\
\hline $\begin{array}{l}\text { Gender no (\%) } \\
\text { Female } \\
\text { Male }\end{array}$ & $\begin{array}{l}234(67.4) \\
113(32.6)\end{array}$ & $\begin{array}{l}67(69.1) \\
30(30.9)\end{array}$ & $\begin{array}{l}167(66.8) \\
83(33.2)\end{array}$ & 0.69 \\
\hline $\begin{array}{l}\text { Medical history no (\%) } \\
\text { Obesity } \\
\text { Hypertension } \\
\text { Cardiovascular diseases } \\
\text { Diabetes } \\
\text { Chronic Respiratory } \\
\text { Diseases } \\
\text { Immunosuppression } \\
\text { Cancer/ Blood disease } \\
\text { Tobacco } \\
\text { No medical history }\end{array}$ & $\begin{array}{c}23(6.6) \\
13(3.8) \\
4(1.2) \\
5(2) \\
21(6.1) \\
1(0.3) \\
6(1.7) \\
32(9.2) \\
242(69.7)\end{array}$ & $\begin{array}{c}8(8.3) \\
3(3.1) \\
1(1) \\
0(0) \\
6(6.2) \\
0(0) \\
0(0) \\
7(7.2) \\
66(68.0)\end{array}$ & $\begin{array}{c}15(6) \\
10(4) \\
3(1.2) \\
5(1.4) \\
15(6) \\
1(0.4) \\
6(2.4) \\
25(10) \\
176(70.4)\end{array}$ & $\begin{array}{l}0.45 \\
0.69 \\
0.89 \\
0.16 \\
0.95 \\
0.53 \\
0.12 \\
0.42 \\
0.67\end{array}$ \\
\hline $\begin{array}{l}\text { Occupation no (\%) } \\
\text { Medical / paramedical } \\
\text { professional } \\
\text { Non-medical field or no } \\
\text { occupation/retired }\end{array}$ & $\begin{array}{l}129(37.2) \\
218(62.8)\end{array}$ & $\begin{array}{l}77(79.4) \\
20(20.6)\end{array}$ & $\begin{array}{l}52(20.8) \\
198(79.2)\end{array}$ & $<0.05^{*}$ \\
\hline
\end{tabular}

* statistically significant $(p<0.05)$ 


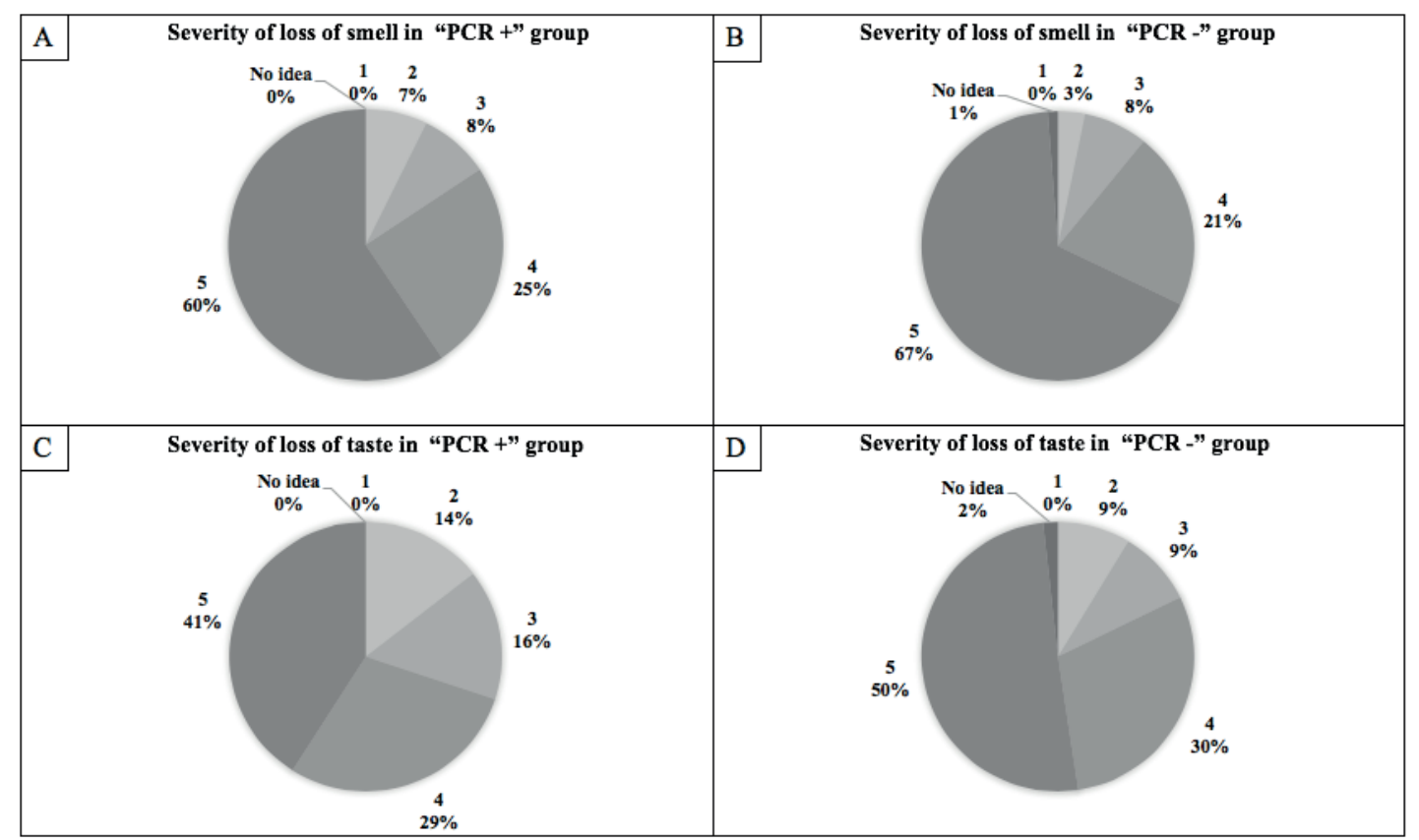

Figure 1. Comparison of self-rating of the severity of loss of smell ( $A$ and $B$ ) and taste ( $C$ and $D$ ) between the patients with a RT-PCR proven SARSCoV-2 diagnosis ("PCR+" group) and patients with a clinical diagnosis ("PCR -" group). Severity of loss of smell and taste were assessed by the following scales: for smell: 1. normosmia, 2 mild hyposmia, 3. Moderate hyposmia, 4. Severe hyposmia and 5. Anosmia and for taste: 1. Normal taste, 2. Mild loss of taste, 3. Moderate loss of taste, 4. Severe loss of taste and 5. Unable to taste at all. No statistical difference was found between the "PCR + " and "PCR -" groups in terms of severity of loss of smell and taste ( $p>0.05)$.

In a cohort of 347 outpatients, 97 patients (28\%) median age 35 years [20 - 73] had a RT-PCR-proven SARS-CoV-2 infection and 250 patients ( $72 \%)$ median age 38 years [ $18-78]$ ) had a clinical diagnosis (Table 1). Sex ratio was balanced $(p=0.69)$. In the "PCR +" group, 77 patients (79.4\%) were working in the medical/paramedical field versus $52(20 \%)$ in the "PCR -" group $(p<0.05)$. No previous medical history was found in 66 "PCR +" patients (68\%) versus in 176 "PCR -" patients (70.4\%) $(p=0.67)$. Olfactory loss was more frequently associated with flavor perception disorders ( $n=83$ "PCR +" (85.6\%) vs $n=228$ "PCR-" (91.2\%) p=0.12) than with taste loss ( $n=34$ "PCR +" (35.1\%) vs $n=89$ "PCR-" (35.6\%), p=0.92) (Table 2). No statistical difference was found for the self-rating of the severity of olfactory and taste loss (Figure 1). Olfactory loss was an isolated symptom in 6"PCR +" patients (6.2\%) vs. 14 "PCR- " patients (5.6\%) $(p=0.83)$, while it appeared before the onset of other symptoms in $n=6$ "PCR +" (6.2\%) vs. $n=22$ "PCR- " $(8.8 \%)(p=0.42)$, and at the same time as other symptoms in $\mathrm{n}=17$ “PCR +" (17.5) vs. $\mathrm{n}=44$ "PCR- " (17.6). Symptoms associated with loss of smell are reported in Table 2. Only 6 patients had medication (chloroquine $(n=1)$, oral $(n=1)$ or nasal $(n=4)$ corticosteroid therapy). Preliminary results of smell and taste recovery (Table 2 ) showed a higher rate of full recovery of smell in the "PCR +" group ( $n=12$ (12.5\%) vs $n=11$ (4.4\%), $p=0.01$ ) with a two-day difference in median duration symptom (12 days "PCR +" group vs. 10 days "PCR -", $p=0.02$ ).

Post-infectious loss of smell is one of the main causes of olfac- tory loss in adults. Many common viruses, including coronaviruses, are known to cause upper respiratory tract infections, as well as post-infectious loss of smell ${ }^{(3)}$. Usually, middle-age women are predominantly affected, but in SARS-CoV-2-related olfactory loss, recent studies showed that patients were usually younger than 40 years, with a balanced sex ratio ${ }^{(4,5)}$. Patients had fewer comorbidities in this study, due to their younger age but Lechien et al. ${ }^{(4)}$ confirmed that there was no significant association between co-morbidities and the occurrence of smell and taste loss.

A major limitation was the lack of tested patients $n=250(72 \%)$, as testing capacities were and are still limited in our country. Healthcare authorities prioritized the testing of specific groups of patients (symptomatic healthcare workers, severe cases...), which explains the higher number of healthcare workers diagnosed by RT-PCR in this study. Another limitation was the inability to perform olfactory tests because patients were still contagious with a median duration of symptom of 10 days. Olfactory tests are recommended to confirm olfactory loss because of a low correlation to a self-rating olfactory loss. Few studies with olfactory tests are currently available ${ }^{(6,7)}$. Moreover, the severity of loss of smell in mild, moderate, severe hyposmia and anosmia is based in a questionnaire and not in a validated quantitative tool of smell and taste assessment.

Loss of smell and taste is a useful sign for the clinical diagno- 
Table 2. Characteristics of loss of smell and taste associated with SARS-CoV-2 infection.

\begin{tabular}{|c|c|c|c|c|}
\hline & $\begin{array}{l}\text { SARS-Cov-2 patients } \\
\qquad(\mathrm{n}=347)\end{array}$ & $\begin{array}{l}\text { "PCR+" patients } \\
(n=97)\end{array}$ & $\begin{array}{l}\text { "PCR-" patients } \\
(n=250)\end{array}$ & $\begin{array}{c}\text { p-value } \\
\text { "PCR+" vs "PCR-" }\end{array}$ \\
\hline $\begin{array}{l}\text { Type of disorder no. (\%) } \\
\text { Olfactory disorder } \\
\text { Flavor perception disorder } \\
\text { Taste disorder }\end{array}$ & $\begin{array}{l}345(99.4) \\
311(89.6) \\
123(35.5)\end{array}$ & $\begin{array}{c}96(99) \\
83(85.6) \\
34(35.1)\end{array}$ & $\begin{array}{c}249(99.6) \\
228(91.2) \\
89(35.6)\end{array}$ & $\begin{array}{l}0.49 \\
0.12 \\
0.92\end{array}$ \\
\hline $\begin{array}{l}\text { Median duration of symptoms in } \\
\text { days [range] }\end{array}$ & $10[1-43]$ & $12[1-40]$ & $10[1-43]$ & $0.02 *$ \\
\hline $\begin{array}{l}\text { Symptoms presentation no. (\%) } \\
\text { Progressively } \\
\text { Suddenly } \\
\text { No idea } \\
\text { Isolated loss of smell and taste } \\
\text { Loss of smell and taste before the } \\
\text { onset of other symptoms } \\
\text { Same time as other symptoms } \\
\text { Second time after initial symptoms } \\
\text { No idea }\end{array}$ & $\begin{array}{c}41(11.8) \\
251(72.3) \\
55(15.9) \\
20(5.8) \\
28(8.1) \\
61(17.6) \\
223(64.3) \\
15(4.3)\end{array}$ & $\begin{array}{c}18(18.6) \\
63(65) \\
16(16.5) \\
6(6.2) \\
6(6.2) \\
17(17.5) \\
65(67) \\
3(3.1)\end{array}$ & $\begin{array}{c}23(9.2) \\
188(75.2) \\
39(15.6) \\
14(5.6) \\
\\
22(8.8) \\
44(17.6) \\
158(63.2) \\
12(4.8)\end{array}$ & $\begin{array}{c}\mathbf{0 . 0 2 *} \\
0.06 \\
0.84 \\
0.83 \\
\\
0.42 \\
0.99 \\
0.51 \\
0.48\end{array}$ \\
\hline $\begin{array}{l}\text { Symptoms evolution no. (\%) } \\
\text { Constant } \\
\text { Fluctuation } \\
\text { No idea }\end{array}$ & $\begin{array}{c}261(75.2) \\
79(22.8) \\
7(2)\end{array}$ & $\begin{array}{c}74(76.3) \\
22(22.7) \\
1(1)\end{array}$ & $\begin{array}{c}187(74.8) \\
57(22.8) \\
6(2.4)\end{array}$ & $\begin{array}{l}0.77 \\
0.98 \\
0.43\end{array}$ \\
\hline $\begin{array}{l}\text { Loss of smell and taste no. (\%) } \\
\text { As an isolated symptom } \\
\text { Associated with other symp-toms } \\
\text { Fever } \\
\text { Cough } \\
\text { Respiratory problems } \\
\text { Nasal obstruction } \\
\text { Rhinorrhea } \\
\text { Sinus pain } \\
\text { Headache } \\
\text { Sore throat } \\
\text { Digestive problems } \\
\text { Arthralgia - myalgia } \\
\text { Asthenia }\end{array}$ & $\begin{array}{c}21(6.1) \\
326(94) \\
170(41.5) \\
151(43.5) \\
46(13.3) \\
125(36) \\
132(38) \\
91(26.2) \\
166(47.8) \\
14(4) \\
103(29.7) \\
53(15.3) \\
44(12.7)\end{array}$ & $\begin{array}{c}6(6.2) \\
91(93.8 \\
50(51.6) \\
47(48.5) \\
16(16.5) \\
31(32) \\
40(41.2) \\
27(27.8) \\
50(51.6) \\
3(3.1) \\
29(29.9) \\
15(15.5) \\
13(13.4)\end{array}$ & $\begin{array}{c}15(6) \\
235(94) \\
120(48) \\
104(41.6) \\
30(12) \\
94(37.6) \\
92(36.8) \\
64(25.6) \\
116(46.4) \\
11(4.4) \\
74(29.6) \\
38(15.2) \\
31(12.4)\end{array}$ & $\begin{array}{l}0.95 \\
\\
0.55 \\
0.25 \\
0.27 \\
0.33 \\
0.44 \\
0.67 \\
0.39 \\
0.58 \\
0.96 \\
0.95 \\
0.80\end{array}$ \\
\hline $\begin{array}{l}\text { Loss of smell as the strongest } \\
\text { symptom }\end{array}$ & $127(39.3)$ & $29(33)$ & $98(41.7)$ & 0.15 \\
\hline $\begin{array}{l}\text { Recovery } \mathbf{n}(\%) \\
\text { Full recovery of smell } \\
\text { Full recovery of taste } \\
\text { Partial recovery of smell } \\
\text { Partial recovery of taste } \\
\text { No recovery of smell } \\
\text { No recovery of taste } \\
\text { Worsening }\end{array}$ & $\begin{array}{c}23(6.7) \\
26(8.3) \\
131(37.8) \\
126(40.3) \\
186(53.9) \\
158(50.2) \\
4(1.2)\end{array}$ & $\begin{array}{c}12(12.5) \\
9(10.8) \\
42(43.8) \\
37(44.6) \\
41(42.7) \\
36(43.4) \\
1(1)\end{array}$ & $\begin{array}{c}11(4.4) \\
17(7.4) \\
89(35.7) \\
89(38.7) \\
145(58.2) \\
122(52.6) \\
3(1.2)\end{array}$ & $\begin{array}{c}\mathbf{0 . 0 1 *} \\
0.33 \\
0.12 \\
0.35 \\
\mathbf{0 . 0 1 *} \\
0.15 \\
0.89\end{array}$ \\
\hline
\end{tabular}

* statistically significant $(p<0.05)$

sis of SARS-CoV-2 infection as it manifests early in the disease process in 109 patients (31.5\%). Early reports referred to isolated loss of smell as a tell-tale sign of a SARS CoV-2. However, this was the least common situation, occurring in 48 patients (13.9\%) either isolated or before other symptoms, which matches the results obtained by Hopkins et al. ${ }^{(5)}$ (13\%) and Lechien et al. ${ }^{(4)}$ Nasosinusal symptoms associated with loss of sense of smell have been frequently reported in this study and in the literature. Results are highly variable, ranging from "generally no sinonasal symptoms" (8) to " $81.1 \%$ of nasal congestion with rhinorrhea"
(4). At the acute phase of an upper respiratory tract infection, olfactory disorders may be caused by severe inflammation of the nasal mucosa with nasal obstruction blocking the passage of olfactory molecules to the olfactory clefts. However, the SARS-CoV-2 is known to be a neurotropic virus that can spread from the peripheral olfactory system to the central system. The hypothesis of direct damage of the olfactory pathways by the SARS-CoV-2 is highly probable, and could explain olfactory loss, in patients without sinonasal symptoms or with persistent olfactory loss after the acute phase of the infection ${ }^{(9)}$. 
In conclusion, during the SARS-CoV-2 pandemic, this study showed that outpatients with loss of smell and taste with a clinical diagnosis had strong similarities with the RT-PCR proven SARSCoV-2 patients and should be considered positive. However, the presence of this symptom cannot replace a diagnosis by RT-PCR.

\section{Conflict of interest}

The authors state that they have no conflict of interest.

\section{Acknowledgement}

None.

\section{References}

1. Gane SB, Kelly C, Hopkins C. Isolated sudden onset anosmia in COVID-19 infection. A novel syndrome? Rhinology. 2020;58(3):299301.

2. Seok J, Shim YJ, Rhee C-S, Kim J-W Correlation between olfactory severity ratings based on olfactory function test scores and self-reported severity rating of olfactory loss. Acta Otolaryngol (Stockh). 2017;137(7):750-4.

3. Suzuki M, Saito K, Min W-P, et al. Identification of viruses in patients with postviral olfactory dysfunction. Laryngoscope. 2007;117(2):272-7.

4. Lechien JR, Chiesa-Estomba CM, De Siati DR, et al. Olfactory and gustatory dysfunctions as a clinical presentation of mild-tomoderate forms of the coronavirus disease
(COVID-19): a multicenter European study. Eur Arch Otorhinolaryngol. 2020 Apr 6:1-11.

5. Hopkins C, Surda P, Kumar N. Presentation of new onset anosmia during the COVID-19 pandemic. Rhinology. 2020;58(3):295-298.

6. Moein ST, Hashemian SMR, Mansourafshar B, Khorram-Tousi A, Tabarsi P, Doty RL. Smell dysfunction: a biomarker for COVID-19. Int Forum Allergy Rhinol. 2020;10.1002/ alr.22587

7. Ottaviano G, Carecchio M, Scarpa B, Marchese-Ragona R. Olfactory and rhinological evaluations in SARS-CoV-2 patients complaining of olfactory loss. Rhinology. 2020 Apr 27. doi: 10.4193/Rhin20.136.

8. Xydakis MS, Dehgani-Mobaraki P, Holbrook $\mathrm{EH}$, et al. Smell and taste dysfunction in patients with COVID-19. Lancet Infect Dis. 2020 Apr 15:S1473-3099(20)30293-0.
9. Machado, C., Gutierrez, J.V. Anosmia and Ageusia as Initial or Unique Symptoms after SARS-COV-2 Virus Infection. Prepr 2020 :2020040272.

\section{Dr. Marion Renaud \\ 1 avenue Molière \\ 67200 Strasbourg \\ France}

Tel : + 33-3-88-127644

E-mail :

marion.renaud@chru-strasbourg.fr

This paper contains supplementary materials online: at www.rhinologyjournal.org 


\section{SUPPLEMENTARY INFORMATION}

Annex 1. 28-questions survey.

$\begin{array}{ll}\text { 1. Agreement to participate in the study } & \square \text { Yes } \quad \square \text { No } \\ \text { 2. Are you living in East of France? } & \square \text { Yes } \quad \square \text { No } \\ \text { 3. Date of birth } & \\ \text { 4. Age } & \\ \text { 5. What is your gender? } & \square \text { Male } \square \text { Female } \\ \text { 6. Are you working in the medical/paramedical field? } \quad \square \text { Yes } \square \text { No }\end{array}$

7. What is your occupation?

8. What type of problem do you have?

$\square$ Olfactory loss

$\square$ Flavor perception disorder

$\square$ Taste loss (inability to detect the four basic tastes: sweet, salty, sour and bitter)

9. When did the problem start? (exact date if possible)

\begin{tabular}{|c|c|c|}
\hline 10. How did it start? & $\square$ Progressively $\square$ Suddenly & 口I don't know \\
\hline 11. Do you have any associated symptoms? & $\begin{array}{l}\square \text { No } \\
\square \text { Fever } \\
\square \text { Asthenia } \\
\square \text { Sinus pain } \\
\square \text { Nasal obstruction } \\
\square \text { Rhinorrhea } \\
\square \text { Sore throat }\end{array}$ & $\begin{array}{l}\square \text { Headache } \\
\square \text { Cough } \\
\square \text { Respiratory problems } \\
\square \text { Digestive problems } \\
\square \text { Arthralgia-myalgia } \\
\square \text { Other: .... }\end{array}$ \\
\hline $\begin{array}{l}\text { 12. What is or was the strongest symptom? } \\
\text { (only one answer) }\end{array}$ & $\begin{array}{l}\square \text { Olfactory/taste loss } \\
\square \text { Fever } \\
\square \text { Asthenia } \\
\square \text { Sinus pain } \\
\square \text { Nasal obstruction } \\
\square \text { Rhinorrhea } \\
\square \text { Sore throat } \\
\square \text { Headache }\end{array}$ & $\begin{array}{l}\square \text { Cough } \\
\square \text { Respiratory problems } \\
\square \text { Digestive problems } \\
\square \text { Arthralgia-myalgia } \\
\square \text { I don't know } \\
\square \text { All symptoms had the same intensity } \\
\square \text { Other: .... }\end{array}$ \\
\hline 13. How did your loss of smell and taste come about? & $\begin{array}{l}\square \text { Isolated } \\
\square \text { Before the onset of the other symptoms } \\
\square \text { Same time as other symptoms } \\
\square \text { Second time after initial symptoms } \\
\square \text { I don't know }\end{array}$ & \\
\hline $\begin{array}{l}\text { 14. Is your loss of smell and taste fluctuating or } \\
\text { constant? }\end{array}$ & $\square$ Fluctuating $\quad \square$ Constant $\quad \square$ Idon't & how \\
\hline $\begin{array}{l}15 . \text { At the onset of your loss of smell, how severe was } \\
\text { your loss on a scale of } 1 \text { to } 5(1=\text { normal and } 5=\text { total } \\
\text { loss)? }\end{array}$ & $\begin{array}{l}1 \text { Able to smell normally (normosmia) } \\
2 \text { Mild hyposmia } \\
3 \text { Moderate hyposmia } \\
4 \text { Severe hyposmia } \\
5 \text { Unable to smell at all (very severe smell lo }\end{array}$ & or anosmia) \\
\hline 16. How is your loss of smell progressing? & $\begin{array}{l}\square \text { Full recovery of smell } \\
\square \text { Partial recovery of smell }\end{array}$ & $\begin{array}{l}\square \text { No recovery } \\
\square \text { Worsening }\end{array}$ \\
\hline $\begin{array}{l}\text { 17. If you have a full recovery, how long did it take } \\
\text { you to recover? }\end{array}$ & $\begin{array}{l}\square<3 \text { days } \\
\square 3-7 \text { days } \\
\square 7-14 \text { days }\end{array}$ & $\begin{array}{l}\square 2 \text { to } 3 \text { weeks } \\
\square 3 \text { to } 4 \text { weeks }\end{array}$ \\
\hline $\begin{array}{l}\text { 18. At the onset of your loss of taste, how severe was } \\
\text { your loss on a scale of } 1 \text { to } 5(1=\text { normal and } 5=\text { total } \\
\text { loss)? }\end{array}$ & $\begin{array}{l}1 \text { Normal taste } \\
2 \text { Mild loss of taste } \\
3 \text { Moderate loss of taste } \\
4 \text { Severe loss of taste } \\
5 \text { Unable to taste at all (agueusia) }\end{array}$ & \\
\hline 19. How is your loss of taste progressing? & $\begin{array}{l}\square \text { Full recovery of smell } \\
\square \text { Partial recovery of smell }\end{array}$ & $\begin{array}{l}\square \text { No recovery } \\
\square \text { Worsening }\end{array}$ \\
\hline $\begin{array}{l}\text { 20. If you have a full recovery, how long did it take } \\
\text { you to recover? }\end{array}$ & $\begin{array}{l}\square<3 \text { days } \\
\square 3-7 \text { days } \\
\square 7-14 \text { days }\end{array}$ & $\begin{array}{l}\square 2 \text { to } 3 \text { weeks } \\
\square 3 \text { to } 4 \text { weeks }\end{array}$ \\
\hline $\begin{array}{l}\text { 21. Do you have had a treatment for your loss of smell } \\
\text { and taste? }\end{array}$ & $\square$ Yes $\square$ No & \\
\hline
\end{tabular}


22. If yes, what was it?

23. Do you have a history of loss of smell?

24. If yes, which etiology?

25. Do you have a medical his-tory? $\square$ Yes $\square$ No

$\square$ A head trauma

$\square$ An upper respiratory tract infection

$\square$ A chronic Rhinosinusitis

$\square$ Other: ....

$\square$ Hypertension

$\square$ Diabetes

$\square$ Chronic respiratory disease

$\square$ Cardiovascular disease

$\square$ Immunosuppression

$\square$ Recent cancer or blood disease

$\square$ Obesity

$\square$ Active smoking

$\square$ No medical history

$\square$ Other: ....
26. Did you have a SARS-CoV-2 test (RT-PCR)?

27. If yes, was is positive?

28. What type of care have you had? $\square$ Yes $\square$ No

$\square$ Yes $\square$ No

$\square$ Ambulatory care

$\square$ Hospitalization in a medical department or in reanimation * 